\title{
URINARY IODINE LEVELS OF PRIMARY SCHOOL CHILDREN IN ILORIN, NIGERIA
}

\author{
Olasinde T. Yetunde, ${ }^{1}$ Adesiyun O. Omotayo, ${ }^{2}$ Olaosebikan R. Rasaq, ${ }^{2}$ Olasinde Adeola, ${ }^{3}$ \\ Ibraheem M. Rasheedat, ${ }^{2}$ Biliaminu A. Sikiru, ${ }^{4}$ Areola D. Emmanuel, ${ }^{5}$ Ernest K. Samuel ${ }^{2}$ \\ ${ }^{1}$ Department of Paediatrics, Bowen University Iwo, Nigeria \\ ${ }^{2}$ Department of Paediatrics, University of Ilorin, Ilorin, Nigeria \\ ${ }^{3}$ Kwara State Ministry of Health, Ilorin, Nigeria \\ ${ }^{4}$ Department of Chemical Pathology, University of Ilorin, Ilorin, Nigeria \\ ${ }^{5}$ Department of Physiology, University of Ilorin, Ilorin, Nigeria
}

Primljen/Received 06. 03. 2020. god.

Abstract: Background: Iodine deficiency is one of the commonest micronutrient deficiencies. Globally, it is the commonest cause of preventable mental retardation and also associated with impaired physical growth. The current iodine nutrition of school children in Ilorin, North-Central Nigeria is not known.

Objective: The study aimed to determine the urinary iodine levelsv(UIL) of school children in Ilorin and explored the relationship with socio-demographic variables.

Methods: This cross-sectional study was carried out among primary schools children in Ilorin, Nigeria. We recruited school children aged 6-12 years through a multi-staged sampling method. Relevant data including socio-demograhic variables were obtained with a pretested study proforma. The recruited school children had urinary iodine determined using the Sandell-Kolthoff method. Data analysis was with Statistical Package for Social Sciences version 20.0.

Results: The median with interquartile range (IQR) of urinary iodine level was $117.2(99.6-148.6) \mu \mathrm{g} / \mathrm{L}$. Of the 480 recruited children, $336(70.0 \%)$ had normal urinary iodine levels while $144(25 \%)$ had mild iodine deficiencyand two $(0.4 \%)$ had excess urinary iodine levels. Pupils with iodine deficiency was higher among public schools than those in private schools $(33.3 \%$ vs $\left.23.6 \%, \chi^{2}=150.149, p<0.022\right)$. The median UIL of the age-group 6-9 years was higher than the 10-12year age group $(\boldsymbol{p}=\mathbf{0 . 0 2 6})$. However, the median UIL values were comparable across gender, socioeconomic strata and mother's educational level.

Conclusions: This study showed that a quarter of the children still had mild iodine deficiency despite salt
Prihvaćen/Accepted 12. 04. 2020. god.

iodisation policy adopted by the country. Also, the iodine levels were not influenced by socio-demographics.

Key words: Urinary iodine, Primary school children, Ilorin, Nigeria.

\section{INTRODUCTION}

Malnutrition remains an important public health concern in the developing countries with micronutrient deficiency accounting for $7 \%$ of the global disease burden (1). Globally, iodine deficiency is one of the commonest micronutrient deficiencies (2). Severe iodine deficiency causes stunted physical growth and it is the commonest cause of preventable mental retardation $(3,4)$.

Globally, about two billion people, most of whom are domiciled in the Sub-Saharan Africa and South Asia have inadequate iodine intake $(3,5)$. One third of these are school-aged children; and nearly half of these children live in West Africa $(3,5)$. Iodine deficiency has been previously reported in different parts of Nigeria, including Ilorin, Kwara State, the present study site $(6,7,8)$.

The World Health Organisation (WHO) introduced the universal salt iodisation to curb this menace, and recommends that the iodine nutrition of a population be monitored at least once every ten years using the urinary iodine levels (UIL) of school-aged children in that population as an indicator $(5,9)$. This is in order to evaluate the iodisation programme in that population.

Urinary iodine determination is a cheap, easy and effective way of measuring body iodine. About $90 \%$ of absorbed iodine is excreted by the kidneys; therefore its urinary level is a sensitive bio-marker of current iodine intake (5). On the other end of the spectrum is exces- 
sive iodine nutrition, which may lead to iodine-induced hyperthyroidism(IIH) (4). This has been reported in some African countries including Nigeria due to consumption of excessively iodised salt $(3,6,10,11,12)$.

The ongoing salt iodisation program in Nigeria and the $\mathrm{WHO}$ recommendation of frequent monitoring of the iodine nutrition of a populace makes its imperative to frequently sample school children for their iodine levels in the developing countries where iodine deficiencies are more prevalent. Furthermore, the earlier study conducted in Ilorin about two decades ago showed a high prevalence of iodine deficiency, and the current status of iodine levels in the school children is unknown. Hence, the need for the generation of more recent data on the iodine levels of school-aged children in Ilorin. This study therfore, aimed to determine the urinary iodine levels of school-aged children in Ilorin, Kwara State, Nigeria, and explore the relationship between UIL and socio-demographics.

\section{METHODS}

We carried-out a cross-sectional descriptive study between February $8^{\text {th }} 2016$ and May $13^{\text {th }} 2016$ in 16 primary schools; 3 public and 13 private schools (with proportionate representation of public and private schools) in Ilorin West Local Government Area of Ilorin, Kwara State, North-Central region of Nigeria. Ilorin West LGA has 260 registered primary schools: 55 public and 205 private primary schools Ilorin City lies in the Precambrian Basement complex of northern Nigeria and is underlain by rock of metamorphic and igneous type, therefore prone to iodine deficiency (13). The minimum sample size required for the study was estimated using the Cochran's formula; $\left[n=\left(z^{\mathrm{T}} \mathrm{pq}\right) / d^{\mathrm{T}} 2\right]$, and used a prevalence of iodine deficiency of $56.3 \%$ previously reported in Nigeria (14) at a tolerable margin of error of $5 \%$.

The participants were selected through a multi-staged sampling technique using the school list obtained from the State Ministry of Education. Schools were stratified into public and private. Proportional allocation was used to select the number of public to private schools used based on the calculated ratio of public to private schools in the LGA. i.e 55:205 =1:4. Therefore, 3 public and 13 private schools were selected.

A table of random numbers was then used to select 3 public and 13 private schools sampled based on their serial numbers on the school register from the Ministry of Education. This was done separately for the public and private schools. The number of children selected in each primary school was obtained by dividing the total number of pupils to be recruited (calculated sample si$\mathrm{ze}=411$ ) by the total number of schools (16) to be sampled in Ilorin West LGA. For easy recruitment of subjects, 30 pupils were recruited from each selected pri- mary school in Ilorin West LGA. In each selected primary school, the pupils were stratified into their classes (basics 1-6) and pupils were recruited from each class. The number of children selected from each class was calculated by dividing the total number of children to be selected from that school by 6 (representing 6 classes from basics 1 to 6 ). Thus, 5 children were recruited from each class in the selected primary school in Ilorin West LGA. In a situation where there was more than one arm in a class, simple random (by balloting) method was used for the selection of a single arm of the class which formed the sampling frame. In each class, using the class register, the pupils were stratified based on their sex; and the ratio of the boys to girls in the class was determined. Proportional allocation was then used to determine the number of boys and girls to be recruited in the class based on their ratio. Simple random sampling by balloting was used to select the required number of boys and girls to make a total of 5 pupils recruited in each class.

Semi-structured questionnaires were used to obtain relevant history and socio-demographic information from the parents of the participants. A total of 480 primary school pupils were recruited into the study; 90 from public and 390 from private primary schools.

Children aged 6-12 years who were apparently healthy and whose parents gave consent were included in the study, while children with cardiac arrhythmias on amiodarone, an iodine containing drug; children with hyperthyroidism on antithyroid drugs such as propylthiouracil, carbimazole and methimazole; and children whose parents / guardians did not give informed consent were excluded from the study.

Parental educational level and occupation was used to calculate the child's social class using adapted Oyedeji (15) classification into upper, middle and lower classes. Ten millilitre $(10 \mathrm{ml})$ of Spot urine samples were collected from the pupils into clean universal bottles with the lid tightly screwed and transported in ice-packs to the Chemical Pathology Laboratory of the University of Ilorin Teaching Hospital (UITH) where they were kept in the refrigerator at $2-8{ }^{\circ} \mathrm{C}$ till analysis. Samples were pooled and analysed in batches.

Urinary iodine was tested using the Sandell-Koltkoff method. It is based on the Sand-ell-Kolthoff reaction which measures the rate of colour disappearance of ceric ammonium sulphate in urine that is digested with ammonium persulfate. Ceric ammonium sulfate (which is yellow) was reduced to the cerous form (which was colourless), and the reaction was catalysed by iodide. The rate of colour disappearance, as measured by a spectrophotometer determined the iodine content of urine. A standard curve plotted during the analysis was used to extrapolate the concentration of iodine in the urine samples $(9,16)$. 
Urinary iodine level below $100 \mu \mathrm{g} / \mathrm{L}$ was classified as iodine deficiency, levels between 100 and 199 $\mu \mathrm{g} / \mathrm{L}$ as sufficient iodine nutrition, those ranging between 200 and $299 \mu \mathrm{g} / \mathrm{L}$ as more than adequate iodine nutrition while levels above $300 \mu \mathrm{g} / \mathrm{L}$ as excessive iodine nutrition $(5,9)$.

\section{Ethical consideration}

Ethical clearance (with reference number UITH/ CAT/189/19A/342) was obtained from the Ethics and Research Committee of the University of Ilorin Teachng Hospital. Approval was sought from the Kwara State Ministry of Education and Head Teachers of the selected schools. Parental consent was sought from the parents of the selected pupils and the informed consent form was signed by them. In addition, assent was sought from children 10 years and older.

\section{Data analysis}

Data collected on the study pro forma was analyzed using the IBM Statistical Package for Social Sciences (SPSS) $^{\mathrm{Tm}}$ version 20.0 for windows. Frequency distribution tables were generated. Urinary iodine level (UIL) was not normally distributed and was therefore represented as median with interquartile range (IQR). Mann-Whitney-U test was used to compare me- dian values of UIL and Kruskal-Walis test was used when comparing more than two sets of median UIL. Student t-test was used to compare means of normally distributed continuous variables. Differences between proportions of categorical variables were evaluated using the Chi-square test or the Yates continuity corrected Chi square. The confidence level was set at 95\% and level of significance at $p<0.05$.

\section{RESULTS}

\section{Socio-demographic characteristics of the study participants}

A total of four hundred and eighty (480) children were enrolled from sixteen primary schools in Ilorin West LGA. The mean \pm standard deviation (SD) age of the study participants was $8.6 \pm 1.8$ years. Two hundred and thirty-eight (49.6\%) of the children were males and $242(50.4 \%)$ were females, with a male: female (M:F) ratio of $1: 1$. Regarding the highest educational qualification, $76 \%$ of the subjects had mothers with at least a Senior School Certificate (SSCE); only 6.9\% of the subjects had mothers with no formal education. The other socio-demographic parameters are as shown in Table 1.

Among the pupils recruited in this study, $7.9 \%$ were from households that bought salt from unpackaged and

Table 1. Socio-demographic characteristics of the pupils

\begin{tabular}{|l|c|c|c|}
\hline \multicolumn{1}{|c|}{ Variable } & $\begin{array}{c}\text { Frequency } \\
(\mathbf{N}=\mathbf{4 8 0})\end{array}$ & Percentage & $\begin{array}{c}\text { Cumulative } \\
\text { percent }\end{array}$ \\
\hline Age group (years) & & & \\
\hline $6-9$ & 319 & 66.5 & 66.5 \\
\hline $10-12$ & 161 & 33.5 & 100.0 \\
\hline Sex & & & 49.6 \\
\hline Male & 238 & 49.6 & 100.0 \\
\hline Female & 242 & 50.4 & 41.3 \\
\hline Educational Status of Father & & & 83.6 \\
\hline Post-secondary & 198 & 41.3 & 96.2 \\
\hline Secondary & 203 & 42.3 & 100.0 \\
\hline Primary & 61 & 12.7 & 27.0 \\
\hline No Formal Education & 18 & 3.7 & 76.0 \\
\hline Educational Status of Mother & & & 93.1 \\
\hline Post-secondary & 130 & 27.0 & 100.0 \\
\hline Secondary & 235 & 49.0 & 86.9 \\
\hline Primary & 82 & 17.1 & 92.7 \\
\hline No Formal Education & 33 & 6.9 & 93.5 \\
\hline Ethnicity & & & \\
\hline Yoruba & 417 & 86.9 & \\
\hline Igbo & 28 & 5.8 & 56.0 \\
\hline Hausa & 4 & 0.8 & 100.4 \\
\hline Others & 31 & 6.5 & \\
\hline Social class & & & \\
\hline High (class I \& II) & 269 & 56.0 & \\
\hline Middle (class III) & 165 & 34.4 & \\
\hline Low (class IV \& V) & 46 & 9.6 & \\
\hline & & & \\
\hline
\end{tabular}


Table 2. Characteristics of salt consumed by study participants

\begin{tabular}{|l|c|c|}
\hline \multicolumn{1}{|c|}{ Variable } & $\begin{array}{c}\text { Frequency } \\
\mathbf{( N = 4 8 0 )}\end{array}$ & Percentage \\
\hline Salt Packaging & & 90.8 \\
\hline Sealed Nylon & 436 & 7.9 \\
\hline Loose in bowls & 38 & 1.3 \\
\hline In Jute/woven sacks & 6 & \\
\hline Storage of salt & 65 & 13.5 \\
\hline Nylon & 393 & 81.9 \\
\hline Tightly closed container & 17 & 3.5 \\
\hline Open container & 5 & 1.1 \\
\hline Sacks & 358 & 74.6 \\
\hline Awareness about salt iodization & 122 & 25.4 \\
\hline Yes & & \\
\hline No & 261 & 72.9 \\
\hline Utilisation of iodized salt $(\mathbf{n}=\mathbf{3 5 8})$ & 97 & 27.1 \\
\hline Yes & & \\
\hline No & 210 & 43.8 \\
\hline Look out for iodine in ingredient list & 270 & 56.2 \\
\hline Yes & & \\
\hline No & & \\
\hline
\end{tabular}

Table 3. Urinary iodine status of study participants

\begin{tabular}{|l|c|c|}
\hline \multicolumn{1}{|c|}{ Iodine level } & $\begin{array}{c}\text { Frequency } \\
(\mathbf{N = 4 8 0 )}\end{array}$ & Percent \\
\hline Mild deficiency & 122 & 25.4 \\
\hline Normal & 334 & 69.6 \\
\hline Above normal & 22 & 4.6 \\
\hline Excess urinary iodine & 2 & 0.4 \\
\hline
\end{tabular}

Severe iodine deficiency: UIL $=0-19 \mu \mathrm{g} / \mathrm{L}$, Moderate iodine deficiency: $\mathrm{UIL}=20-49 \mu \mathrm{g} / \mathrm{L}$, Mild deficiency: $\mathrm{UIL}=50-99 \mu \mathrm{g} / \mathrm{L}, \mathrm{Nor}-$ mal iodine level: UIL $=100-199 \mu \mathrm{g} / \mathrm{L}$, Above normal iodine level: UIL $=200-299 \mu \mathrm{g} / \mathrm{L}$, Excess urinary iodine: UIL: $>300 \mu \mathrm{g} / \mathrm{L}$

Table 4. Comparison of iodine nutrition across the public and private schools

\begin{tabular}{|l|c|c|c|c|c|}
\hline \multicolumn{1}{|c|}{ Variable } & $\begin{array}{c}\text { Total } \\
\mathbf{N = 4 8 0}\end{array}$ & $\begin{array}{c}\text { Private } \\
\mathbf{n = 3 9 0}\end{array}$ & $\begin{array}{c}\text { Public } \\
\mathbf{n = 9 0}\end{array}$ & U or $\chi^{\mathbf{2}}$ & $\boldsymbol{p}$ value \\
\hline UIL (Fg/L) & 117.2 & 117.2 & 116.8 & $16734.000^{\mathrm{U}}$ & 0.392 \\
\hline Median & $99.6-148.6$ & $101.4-149.3$ & $88.4-147.3$ & & \\
\hline Inter-quartile range & & & & & \\
\hline UIL group & $122(25.4)$ & $92(23.6)$ & $30(33.3)$ & $8.244^{\mathrm{y}}$ & $\mathbf{0 . 0 4 1}$ \\
\hline Mild deficiency & $334(69.6)$ & $283(72.6)$ & $51(56.7)$ & & \\
\hline Normal & $22(4.6)$ & $14(3.5)$ & $8(8.9)$ & & \\
\hline Above normal & $2(0.4)$ & $1(0.3)$ & $1(1.1)$ & & \\
\hline Excess & & & & \\
\hline
\end{tabular}

U: Mann Whitney U test; y: Yates corrected chi square; UIL: Urinary iodine level 
Table 5. Relationship between the median urinary iodine level of participants and their socio-demographic features

\begin{tabular}{|l|c|c|c|}
\hline \multirow{2}{*}{ Variable } & \multicolumn{2}{c|}{ UIL } & U or K \\
\cline { 2 - 4 } & Median (IQR) & & \\
\hline Age group (years) & & & $\mathbf{0 . 0 2 6}$ \\
\hline $6-9$ & $117.2(101.4-153.6)$ & $22490.500^{U}$ & \\
\hline $10-12$ & $115.7(94.2-138.2)$ & & 0.180 \\
\hline Sex & & & \\
\hline Male & $122.0(101.4-150.4)$ & $26759.500^{\mathrm{U}}$ & \\
\hline Female & $117.2(97.9-144.7)$ & & 0.570 \\
\hline Educational Status of Father & & & \\
\hline Post-secondary & $117.2(100.9-152.7)$ & $2.012^{\mathrm{K}}$ & \\
\hline Secondary & $117.2(99.6-148.6)$ & & \\
\hline Primary & $117.2(101.4-137.7)$ & & \\
\hline No formal Education & $114.2(83.5 .9-139.5)$ & & \\
\hline Educational Status of Mother & & & \\
\hline Post-secondary & $117.2(97.9-155.4)$ & $0.612^{\mathrm{K}}$ & \\
\hline Secondary & $117.2(102.2-138.1)$ & & \\
\hline Primary & $117.2(99.6-147.3)$ & & \\
\hline No formal Education & $124.2(100.5-150.5)$ & & \\
\hline Ethnicity & & & \\
\hline Yoruba & $117.2(99.6-149.3)$ & $1.196^{\mathrm{K}}$ & \\
\hline Igbo & $115.6(104.4-130.1)$ & & \\
\hline Hausa & $106.9(91.6-146.7)$ & & \\
\hline Others & $117.2(94.2-153.6)$ & & \\
\hline Social class & & & \\
\hline High (class I \& II) & $115.7(94.2-153.6)$ & $0.591^{\mathrm{K}}$ & \\
\hline Middle (class III) & $122.0(102.2-141.6)$ & & \\
\hline Low (class IV\&V) & $123.7(102.2-148.6)$ & & \\
\hline & & \\
\hline OR & & \\
\hline
\end{tabular}

IQR: Inter-quartile range; U: Mann Whitney U test; K: Kruskal Wallis test; UIL: Urinary iodine level

loose in bowls while $1.3 \%$ bought salt in jute sacks. Three hundred and ninety-three $(81.9 \%)$ pupils belonged to households that stored their salt in tightly closed containers, while $3.5 \%$ left them in open containers. Three hundred and fifty-eight $(74.6 \%)$ of the participants had parents that had heard about salt iodisation, and of these, only $72.9 \%$ use iodised salt. This is as shown in Table 2.

The median (inter-quartile range) urinary iodine level of the study population was 117.2 (99.6-148.6) $\mu \mathrm{g} / \mathrm{L}$. Three hundred and thirty-four $(69.6 \%)$ of the total population screened had normal urine iodine level (UIL) while 122 (25.4\%) children had mild iodine deficiency as shown in Table 3. None of the pupils had moderate or severe iodine deficiency.

Although the median UIL of both school populations were comparable, significantly higher number of pupils in the public schools had mild iodine deficiency than those in the private schools $\left(33.3 \%\right.$ VS $23.6 \% \chi^{2}=$ 150.149 , OR $1.8,95 \%$ CI 1.088 to $3.009, \boldsymbol{p}=\mathbf{0 . 0 2 2}$ ). Other details are shown in Table 4.
Comparing the median urinary iodine level of the school children across the different age groups, there was a significant difference between age and urinary iodine level as shown in Table 5. The median UIL of the age-group 6-9 years was statistically higher than the 10-12-year age group $(\boldsymbol{p}=\mathbf{0 . 0 2 6})$. The median UIL values were comparable across the socio-economic strata, ethnicity and the different levels of father's and mother's education.

\section{DISCUSSION}

Twenty five percent of the study participants had iodine deficiency (mild -UIL between 50 and $99 \mu \mathrm{g} / \mathrm{l}$ ). The $25.4 \%$ prevalence of iodine deficiency in this study is similar to the findings during the year 2001 national study that reported a prevalence of iodine deficiency as $28 \%$ in the State of the present study (8). This may mean that the iodine nutrition has not changed over the years in the State despite the country's iodisation policy. Also, it may be due to the fact that some of 
the study participants were from households that still bought salt in loose, unpackaged forms and large porous woven sacks which are much cheaper. Iodine is very volatile and may evaporate from iodised salt especially when exposed to heat and moisture or stored in porous or open containers (9). Furthermore, the current UNICEF data on salt iodisation estimates that only 3 out 4 households in the world used iodised salt (17). The above factors may have contributed to the mild iodine deficiency seen among the children in this present study.

This study also showed the number of children with mild iodine deficiency was higher among children that attended public schools. This probably reflects the fact that the children in private schools are better nourished than those in public schools. Also, the children from public schools are more likely to come from poorer homes that consume non-iodised salt or salt sold in unpackaged loose forms.

The median UIL (of $117 \mu \mathrm{g} / \mathrm{l}$ ) in this study was much different from the findings in Saki which recorded $285 \mu \mathrm{g} / \mathrm{l}$, a value that is within the 'above normal UIL' range; but similar to the $124 \mu \mathrm{g} / \mathrm{l}$ recently reported inNsukka, South-East, Nigeria $(6,18)$. Furthermore, the $69.6 \%$ prevalence of adequate UIL in this study was much higher than the $8.3 \%$ and $41 \%$ previously reported by Nwaramah et al (14) in Enugu and Augustine (6) in Saki, from South-Eastern and South-Western parts of Nigeria respectively. The difference in prevalence recorded in this study may be because Ilorin, unlike Enugu and Saki, is not in the goitre belt of Nigeria (19).

This study also found that less than $1 \%$ of the children had urinary iodine level above $300 \mu \mathrm{g} / \mathrm{l}$. This is suggestive of excess iodine nutrition. The prevalence of excessive iodine level in this study is very much lower than the $50 \%$ and $67 \%$ reported in South-west Nigeria $(6,12)$. This suggests that Ilorin populace is not presently at risk of IIH but regular monitoring the UIL of the populace is pertinent to prevent IIH. The low prevalence of excess UIL in this study may also be because Ilorin populace is not in the goitre belt of Nigeria; IIH occurs in populations which previously had chronic iodine deficiency (9).

Comparing the median UIL across the different age groups, the 6 to 9year olds had the highest median value, while the 10-12year olds had the least value. Amor et al (20) in India had earlier documented variation of UIL with age, although contrary to this study, he reported increasing UIL values with age. The possible reason for the decrease in iodine with increasing age recorded in this study may be the increased need for iodine for growth in this age-group, which marks the beginning of the adolescent years and growth spurt.

The findings in this study were consistent with the findings of Alozie et al (7) in Akwa-Ibom, South-south
Nigeria and Skeaff et al (21) in New Zealand who reported no gender variation in UIL of population studied. This is however contrary to the findings from Enugu in South-east and Cross-River state in South-south Nigeria that reported more cases of iodine deficiency in boys than girls $(14,22)$. The reason for no gender variation with UIL reported in this study is unclear but could possibly be that households that use iodised salt for general cooking do so without prejudice to both genders in the households.

The median UIL in the present study population was comparable across the different socio-economic strata. This might be due to availability and usage of iodised salt by majority ( $72.9 \%$ ) of households, in the community this study was carried out. This is in agreement with earlier studies by Skeaff (21) in New Zealand and Volzke (23) in Germany but contrasts Low (24) in Malaysia, who reported variations in UIL in subjects across different socioeconomic classes.

\section{CONCLUSION}

This study showed that a quarter of the children still have mild iodine deficiency despite the salt iodisation policy adopted by the country. Iodine deficiency was more marked in public schools than in private schools. Also, the urinary iodine levels were not influenced by socio-demographics.

Conflict of Interests: The authors declare that there are no conflicts of interest related to this article.

Funding: The Research was funded by the authors.

\section{Acknowledgement}

Special thanks to Mrs Bimpe Kolawole of the Kwara State Ministry of Education, all Head Teachers of the selected schools and the Quality and Assurance department of the Kwara State Ministry of Education for approval of this work.

\section{AUTHOR CONTRIBUTION}

Y.T.O., O.O.A., R.R.O and S.K.E designed research; Y.T.O, E.D.A and S.A.B. conducted research; Y. T.O and A.O analyzed data; and Y.T.O, A.O and R.M.I. wrote the paper. Y.T.O had primary responsibility for final content. All authors read and approved the final manuscript.

\section{Licensing}

This work is licensed under a Creative Commons Attribution 4.0 International (CC BY 4.0) License. 


\title{
Sažetak
}

\section{NIVO JODA U URINU KOD DECE OSNOVNIH ŠKOLAU ILORINU, NIGERIJI}

\author{
Olasinde T. Yetunde, ${ }^{1}$ Adesiyun O. Omotayo, ${ }^{2}$ Olaosebikan R. Rasaq, ${ }^{2}$ Olasinde Adeola, \\ Ibraheem M. Rasheedat, ${ }^{2}$ Biliaminu A. Sikiru, ${ }^{4}$ Areola D. Emmanuel, ${ }^{5}$ Ernest K. Samuel ${ }^{2}$ \\ ${ }^{1}$ Department of Paediatrics, Bowen University Iwo, Nigeria \\ ${ }^{2}$ Department of Paediatrics, University of Ilorin, Ilorin, Nigeria \\ ${ }^{3}$ Kwara State Ministry of Health, Ilorin, Nigeria \\ ${ }^{4}$ Department of Chemical Pathology, University of Ilorin, Ilorin, Nigeria \\ 5 Department of Physiology, University of Ilorin, Ilorin, Nigeria
}

Uvod: Deficit joda je jedna od najčešćih deficita mikronutritijenata. Ovaj deficit je najčešći uzrok preventivne mentalne retardacije, ali je takođe i povezan sa poremećajem fizičkog rasta. Zastupljenost joda $u$ ishrani kod dece $u$ Ilorinu, Severno-centralnoj Nigeriji do sada nije poznata.

Cilj: Studija ima za cilj da utvrdi nivo joda u urinu (UIL) kod dece školskog uzrasta u Ilorinu i ispita vezu sa socidemografskim varijablama.

Metod: Ova studija je izvedena kod učenika osnovnih škola u Ilorinu, Nigeriji. Uključena su deca uzrasta 6-12 godina, a raspoređena su pomoću multi-stage metode. Relevantni podaci koji su uključivali sociodemografske varijable bili su uzeti sa prethodno sprovedenim pretestom. Metoda Sandell-Kolthoff je korišćena za utvrđivanje nivoa joda u urinu. Analiza podataka sprovedena je koristeći Statistički paket za Društvene Nauke verzija 20.0.

Rezultati: Medijana sa interkvartalnim opsegom (IQR) urinarnog nivoa joda bila je 117.2 (99.6-148.6)

\section{REFERENCES}

1. Muthayya S, Rah JH, Sugimoto JD, Roos FF, Kraemer $\mathrm{K}$, Black RE. The global hidden hunger indices and maps: an advocacy tool for action. PLoS One. 2013; 8(6): e67860.

2. United Nations Standing Committee on Nutrition. 6th Report on the world nutrition situation-progress in nutrition. Geneva, 2010.

3. Zimmermann MB, Jooste PL, Pandav CS. Iodine-deficiency disorders. Lancet. 2008; 372(9645): 1251-62.

4. Eastman CJ, Zimmermann M. The Iodine deficiency disorders. In: De Groot L (ed). Thyroid disease manager. Endocrine education: South Dartmouth, 2009, pp 1-52.

5. WHO. Iodine Status Worldwide :WHO Global Database on Iodine Deficiency. WHO: Geneva, 2004

6. Augustine AO, Anetor J, Nurudeen A, Oyewole O. Assessment of urinary iodine status of primary school children in Saki, in South Western Nigeria. Bull Environ Life Sci. 2012; 1: 5-9.

7. Alozie Y, Assi A, Alozie G. Iodine status of school-aged children in Urue Offong/Oruko Local Government Area of Akwa Ibom State. Niger J Nutr Sci. 2012; 33(1): 42-5.

8. WHO. The WHO global database on iodine deficiency. Geneva, 2007www.who.int/vmnis/iodine/data/database/countries/nga idd.

9. WHO, UNICEF, ICCIDD. Assessment of iodine deficiency disorders and monitoring their elimination- A guide for programme managers. Geneva, 2007. $\mu \mathrm{g} / \mathrm{L}$. Od 480 dece uključene u studiju, 336 (70\%) imalo je normalan nivo joda, dok je 144 (25\%) imalo osrednju deficijenciju joda, dvoje dece $(0.4 \%)$ imalo je povišene vrednosti joda u urinu. Nedostatak joda je bio učestaliji kod dece, koja su pohađala državne osnovne škole od dece koja su pohađala privatne osnovne škole $\left(33.3 \%\right.$ vs $\left.23.6 \%, \chi^{2}=150.149, p<0.022\right)$. Medijana UIL starosne grupe 6-9 godina je bila veća nego kod grupe od 10-12 godina $(\boldsymbol{p}=\mathbf{0 . 0 2 6})$. Bilo kako bilo, medijana UIL vrednosti je bila uporediva između polova, socioekonomskih stratuma, kao i nivoa edukacije majki dece.

Zaključak: Ova studija je pokazala da četvrtina dece i dalje ima osrednji nedostatak joda, uprkos zakonu o obogaćivanju voda i namirnica jodom. Takođe, na vrednosti nivoa joda nisu uticale sociodemografski podaci.

Ključne reči: jod u urinu, deca osnovnih škola, Ilorin, Nigerija.

10. Jooste P, Andersson M. Iodine nutrition in Africa : an update for 2014. Sight Life. 2013; 27(3): 50-5.

11. Andersson M, Karumbunathan V, Zimmermann MB. Global iodine status in 2011 and trends over the past decade. J Nutr. 2012; 142(4): 744-50.

12. Onyeaghala AA, Anetor JI, Nurudeen A, Oyewole OE. High urinary iodine content (UIC) among primary school children in Ibadan, Nigeria, a public health concern. J Toxicol Environ Heal Sci. 2010; 2(7): 93-6.

13. Olatunji S, Johnson L. Determination of seasonal variation of aquifer depth in a part of basement complex of Ilorin metropolis. J Environ Sci Resour. 2012; 4: 67-80.

14. Nwamarah JU, Okeke EC. A pilot study of iodine and anthropometric status of primary school children in Obukpa, a rural Nigerian community. J Public Heal Epidemiol. 2012; 4(9): 246-52.

15. Oyedeji G. Socio-economic and cultural background of hospitalized children in Ilesha, Nigeria. Niger J Paediatr. 1985; 12(4): 111-8.

16. WHO. Urinary iodine concentrations for determining iodine status in populations. Geneva, 2013.

17. UNICEF. Adequately iodized salt can protect children from brain damage, but only three quarters of the world's households are using it. New York, 2016http://www.data.unicef.org/ topic/nutrition/iodine-deficiency (accessed 8 Dec2016).

18. Nwamarah JU, Otitoju O, Otitoju G, Taiwo O, Emewulu U, Chidinma D. Iodine and nutritional status of primary 
school children in a Nigerian Community Okpuje, in Nsukka LGA, Enugu State, Nigeria. Der Pharm Lett. 2015; 7: 271-80.

19. Egbuta J, Onyezili F, Vanormelingen K. Impact evaluation of efforts to eliminate iodine deficiency disorders in Nigeria. Public Health Nutr. 2003; 6(2): 169-73.

20. Amor JD, Padhiyar N, Nimama G. Urinary iodine excretion in urine samples among children in Dahod district, Gujarat. Indian J Clin Pract. 2013; 23(9): 560-4.

21. Skeaff S a, Thomson CD, Wilson N, Parnell WR. A comprehensive assessment of urinary iodine concentration and thyroid hormones in New Zealand schoolchildren: a cross-sectional study. Nutr J. 2012; 11: 31 .

22. Abua SN, Ajayi OA, Sanusi RA, Sabina N. A, Olufunmike A. A, Rasaki A. S. Adequacy of dietary iodine in two local government areas of Cross River State in Nigeria. Pakistan J Nutr. 2008; 7(1): 40-3.

23. Völzke H, Craesmeyer C, Nauck M, Below H, Kramer A, John U et al. Association of socioeconomic status with iodine supply and thyroid disorders in Northeast Germany. Thyroid. 2013; 23(3): 346-53.

\section{Correspondence to/Autor za korespondenciju}

Yetunde T Olasinde

Department of Paediatrics,

Bowen University,

PMB 284, Iwo, Nigeria

Email: yeye1991@yahoo.com

Phone no.: +234-8067016199 